\title{
Interaction of the nematophagous fungus Pochonia chlamydosporia on eggs of Spartocera dentiventris (Berg) (Hemiptera: Coreidae) under laboratory conditions
}

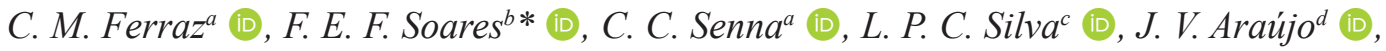 \\ T. F. Moreira ${ }^{\text {(D) , F. C. Monteiro }}{ }^{c}$ (D) and F. R. Braga ${ }^{a}$ (D) \\ ${ }^{a}$ Universidade Vila Velha - UVV, Laboratório de Parasitologia Experimental e Controle Biológico, Vila Velha, ES, Brasil \\ bUniversidade Federal de Lavras - UFLA, Departamento de Química, Lavras, MG, Brasil \\ 'Universidade Federal do Espírito Santo - UFES, Laboratório de Ultraestrutura Celular Carlos Alberto Redins, Vitória, ES, Brasil \\ dUniversidade Federal de Viçosa - UFV, Departamento de Veterinária, Viçosa, MG, Brasil \\ eUniversidade Federal de Minas Gerais - UFMG, Departamento de Clínica e Cirurgia Veterinária, Belo Horizonte, MG, Brasil \\ *e-mail: filippeufv@yahoo.com.br
}

Received: November 28, 2019 - Accepted: July 3, 2020 - Distributed: November 30, 2021

(With 2 figures)

The Spartocera dentiventris (Berg) (Hemiptera: Coreidae), commonly known as "tobacco stink bug" (Nicotiana tabacum) is responsible for causing great damage in tobacco farming, but has also been found in other agricultural crops in Brazil and other parts of the world (Caldas et al., 2000; Jesus et al., 2002). The culture of tobacco has great economic importance, due to its high commercial value and the ability to employ a great number of people (Maliszewski, 2019). However, the exacerbated use of pesticides in tobacco crops is a fact that requires attention, mainly due to the direct risk for the health of peaple involved in tobacco farming, as well as to the environment and to preserve the large entomological biodiversity present in tobacco farming (Silva et al., 2005). In this sense, methods of biological control of pest insects is warranted (Flores-Villegas et al., 2019).

Pochonia chlamydosporia is a nematophagous fungus that can alternatively parasitize eggs, belonging to the Clavicipitaceae family (Ascomycota: Pezizomycotina: Sordariomycetes: Hypocreales) (Mendoza de Gives and Braga, 2018). Recent studies have demonstrated the possible entomopathogenic activity of this fungal species, due to its production of extracellular enzymes of the chitinase type and, with regard to this new aspects, its possible uses have been studied (Braga et al., 2013; Senna et al., 2018). However, there are no reports in the literature that mention the interaction of $P$. chlamydosporia on the hemiptera $S$. dentiventris, which can be an important step in the control of this insect pest and contribute directly to reducing the abuse of pesticides in tobacco culture. Thus, the aim of the present study was to evaluate the interaction of the nematophagous fungus $P$. chlamydosporia (VC4) on eggs of $S$. dentiventris (Berg) (Hemiptera: Coreidae) under laboratory conditions.

Spartocera dentiventris eggs were obtained from fertilized females kept in the laboratory and stored in an oven at $28{ }^{\circ} \mathrm{C}$ and $60 \%$ humidity, according to the methodology proposed by Flores-Villegas et al. (2019). The nematophagous fungus Pochonia chlamydosporia
(VC4) comes from Brazilian soil and has been maintained in the Veterinary Parasitology laboratory of the Federal University of Viçosa (Braga et al., 2013).

The fungus was placed in Petri dishes with $9 \mathrm{~cm}$ in diameter containing $2 \%$ chitin agar medium ( $2 \% \mathrm{WQ})$. After 10 days of growth, the plates were washed with $5 \mathrm{ml}$ of distilled water. With the aid of a glass slide, scraping of the agar surface was carried out to remove fungal structures (conidia e/ou clamidosporos). Subsequently, the solutions were poured into a sterile becker and the mean concertation was calculated after five evaluations. A concentration of 500 fungal structures $/ 100 \mu \mathrm{L}$ was obtained, according to Braga et al. (2013) modified. In this assay, two groups were formed: treated group (G1) and control group (G2). In G1, 500 fungal structures $/ 100 \mu \mathrm{L}$ of the fungus solution were poured over egg in the Petri dishes. In G2 (control) eggs were treated only $100 \mu \mathrm{L}$ of distilled water. Both groups were composed of six Petri dishes (6 cm in diameter) and incubated at $25 \pm 1{ }^{\circ} \mathrm{C}$ and $80 \pm 10 \%$ relative humidity, in the dark, during 30 days. Throughout the experimental period, all plaques from both groups G1 and G2 were visualized. After this period, scanning electron microscopy (SEM) was performed.

For SEM, S. dentiventris eggs from group G1 were washed 3 times in PBS buffer at room temperature and then fixed with $2.5 \%$ glutaraldehyde in $0.1 \mathrm{M}$ cacodylate buffer and fixed in osmium tetroxide ( $1 \%$ of OsO4). The material was dehydrated with ethanol baths in increasing concentrations and after dehydration, the samples were mounted on metal supports, coated with gold and observed using a JEOL JSM 6390LV scanning electron microscope (JEOL, Ltd ., Akishima, Tokyo, Japan) with an amplification of 200-5,000×.

In the G1 group there was no hatching of the eggs, but hatching was observed in the control group G2. In Figure 1A-D, the mycelial interaction and growth of $P$. chlamydosporia (VC4) was observed. The colonization of $S$. dentiventris eggs by $P$. chlamydosporia was confirmed by SEM (Figure 2A-F). This fact was confirmed by the 


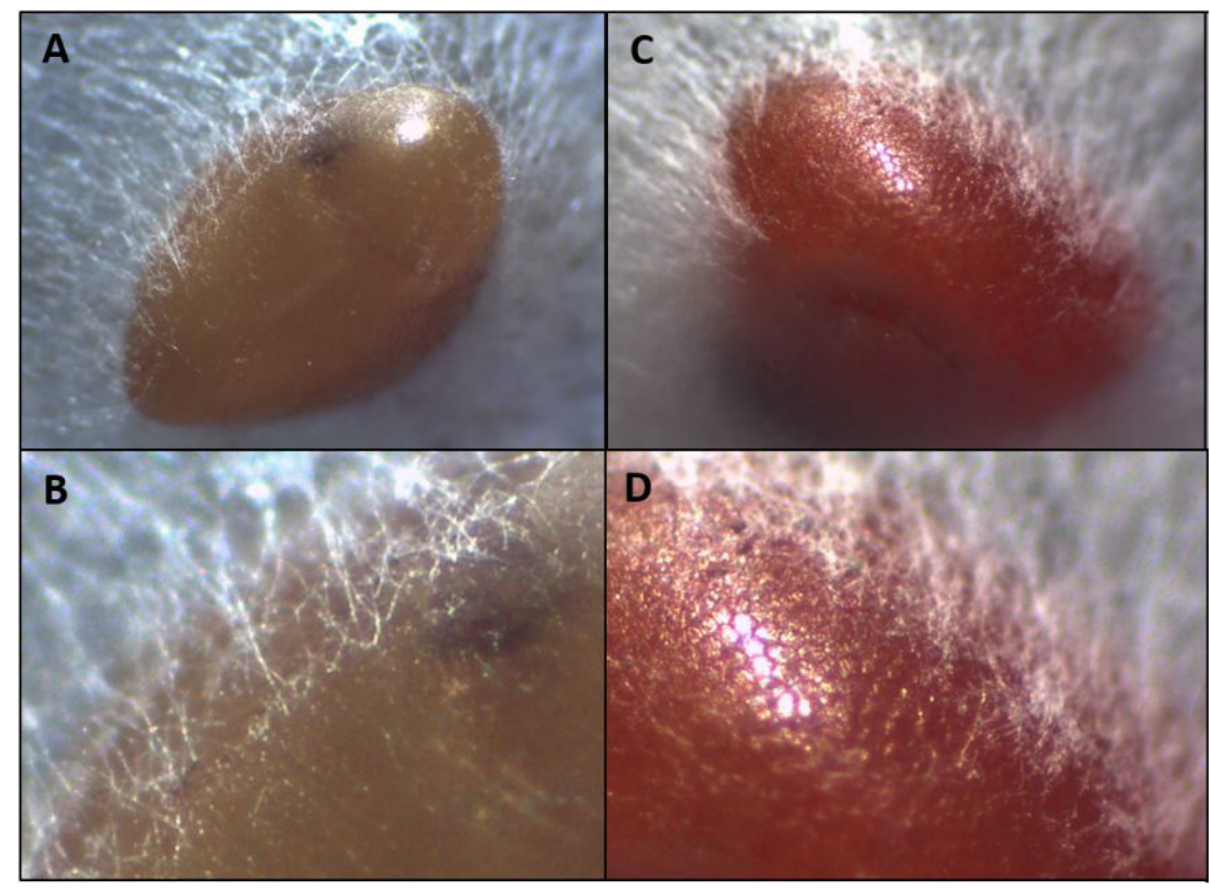

Figure 1. Colonization of eggs of Spartocera dentiventris by fungus Pochonia chlamydosporia.

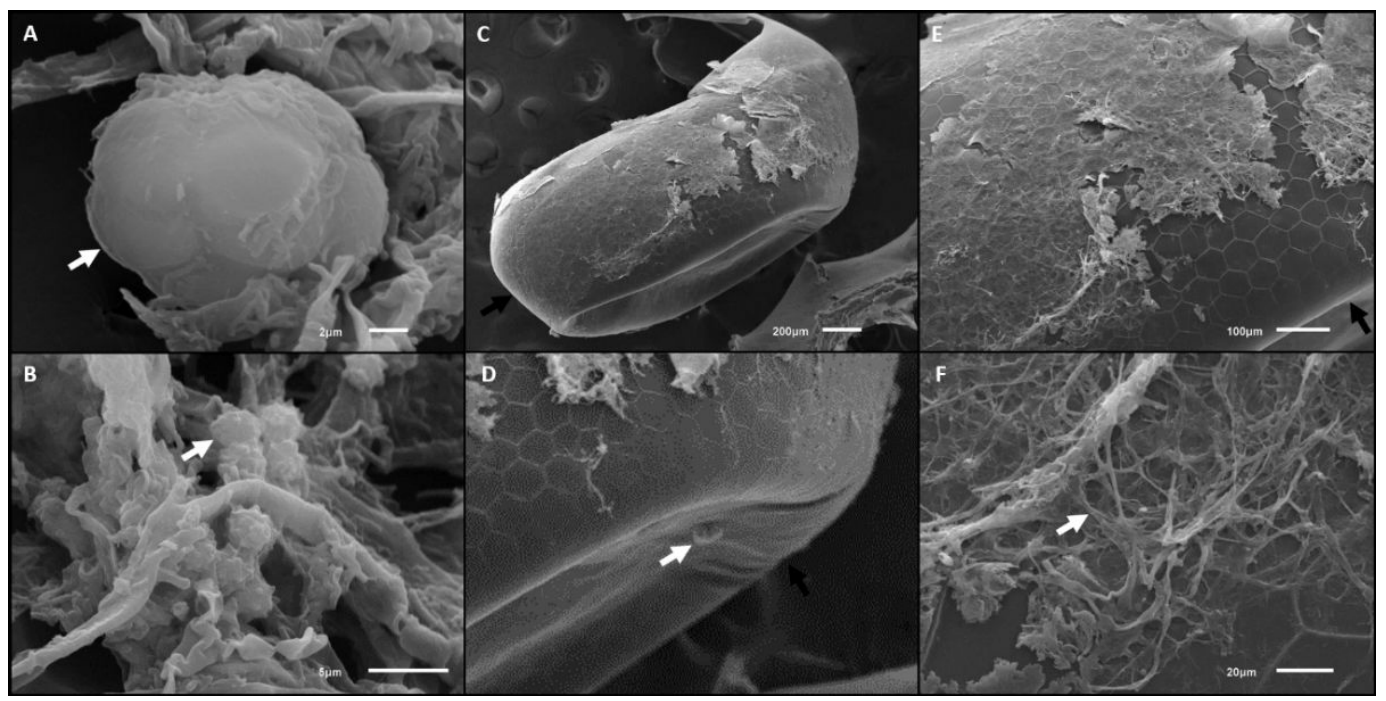

Figure 2. Presence of fungal structures of Pochonia chlamydosporia (white arrow): chlamydospores (A), germination (B), interaction (C), apressorium (D), colonization (E) and hyphae (F) on Spartocera dentiventris eggs (black arrow).

presence of $P$. chlamydosporia chlamydospores seen in SEM (Figure 2A).

$P$. chlamydosporia is not an entomopathogenic fungus, but the interaction and colonization of $S$. dentiventris eggs was observed in the present study. The literature has mentioned that entomopathogenic fungi have been used in laboratory and field experiments to control arthropods (Flores-Villegas et al., 2019). P. chlamydosporia belongs to the same clade as the entomopathogenic fungi Metarhizium spp. and comparative genome analyzes demonstrate that this fungus has 77 chitin-modifying enzymes (Lopez-Moya et al., 2017).

In the present work, a "possible" entomopathogenic activity of $P$. chlamydosporia on $S$. dendiventris eggs was observed. However, it is important to emphasize that cultivation in a rich medium on chitin, provided the conditions for chitinases production (Esteves et al., 2009; Braga et al., 2013; Soares et al., 2015; Senna et al., 2018). However, there is a scarcity of reports regarding the possible entomopathogenic activity of nematophagous fungi. This work is the first report of the 
interaction of the fungus $P$. chlamydosporia (VC4) on eggs of $S$. dentiventris, which in the future may become a tool in controlling this insect in tobacco crops.

\section{Acknowledgements}

Funding from the Conselho Nacional do Desenvolvimento Científico e Tecnológico (CNPq), Coordenação de Aperfeiçoamento de Pessoal de Nível Superior (CAPES), Fundação de Amparo à Pesquisa do Estado de Minas Gerais (FAPEMIG) and Fundação de Amparo à Pesquisa do Estado do Espírito Santo are acknowledged. The authors would like to thank Ricardo Souza, Flávia Laviola and Francielle Veloso for their help.

\section{References}

BRAGA, F.B., ARAÚJO, J.V., SOARES, F.E.F., ARAUJO, J.M., TAVELA, A.O., CARVALHO, L.M., MELLO, I.N.K., PAULA, A.T., LELIS, R. and QUEIROZ, J.H., 2013. Interaction of the nematophagous fungus Duddingtonia flagrans on Amblyomma cajannense engorged females and enzymatic characterisation of its chitinase. Biocontrol Science and Technology, vol. 23, no. 5, pp. 584-594. http://dx.doi.org/10.1080/09583157.2013.789481.

CALDAS, B.-H.C., REDAELLI, L.R. and DIEFENBACH, L.M.G., 2000. Biology of Corecoris dentiventris Berg, 1884 (Hemiptera, Coreidae) in tobacco culture (Nicotiana tabacum). Brazilian Journal of Biology $=$ Revista Brasileira de Biologia, vol. 60, no. 1, pp. 173-178. http://dx.doi.org/10.1590/S003471082000000100020 . PMid:10838936.

ESTEVES, I., PETEIRA, B., ATKINS, S.D., MAGAN, N. and KERRY, B., 2009. Production of extracellular enzymes by different isolates of Pochonia chlamydosporia. Mycological Research, vol. 113, no. Pt 8, pp. 867-876. http://dx.doi.org/10.1016/j. mycres.2009.04.005. PMid:19422912.

FLORES-VILLEGAS, A.L., CABRERA-BRAVO, M., PÉREZTORRES, A., CÓRDOBA-AGUILAR,A., SALAZAR-SCHETTINO, P.M., HERNÁNDEZ-VELÁZQUEZ, V.M. and TORIELLO, C., 2019. Effects on Meccus pallidipennis (Hemiptera: Reduviidae) eggs exposed to entomopathogenic fungi: exploring alternatives to control chagas disease. Journal of Medical Entomology, vol. 56, no. 1, pp. 284-290. http://dx.doi.org/10.1093/jme/tjy186. PMid:30346556.
JESUS, C.R., ROMANOWSKI, H.P. and REDAELLI, L.R., 2002. Movement pattern of Spartocera dentiventris (Berg) (Hemiptera: Coreidae) in an experimental crop of Nicotiana tabacum L. (solanaceae). Brazilian Journal of Biology $=$ Revista Brasileira de Biologia, vol. 62, no. 4B, pp. 827-834. http://dx.doi.org/10.1590/ S1519-69842002000500012. PMid:12659034.

LOPEZ-MOYA, F., ESCUDERO, N. and LOPEZ-LLORCA, L.V. 2017. Pochonia chlamydosporia: multitrophic lifestyles explained by a versatile genome. In: R.H. MANZANILLA-LÓPEZ and L.V. LOPEZ-LLORCA, eds. Perspectives in sustainable nematode management through Pochonia chlamydosporia: applications for root and Rhizosphere health. Cham: Springer, pp. 197-207. http://dx.doi.org/10.1007/978-3-319-59224-4_10.

MALISZEWSKI, E., 2019 [viewed 27 June 2020]. A importância social do tabaco [online]. Agrolink. Available from: https://www. agrolink.com.br

MENDOZA DE GIVES, P. and BRAGA, F.R., 2018. Pochonia chlamydosporia: a promising biotechnological tool against parasitic nematodes and geohelminths. In: R.H. MANZANILLA-LÓPEZ and L.V. LOPEZ-LLORCA, eds. Perspectives in sustainable nematode management through Pochonia chlamydosporia: applications for root and Rhizosphere health. Cham: Springer, pp. 371-383.

SENNA, C.C., SENA, F.P., PAZ, J.S., RIOS, A.B., FERRAZ, C.M., LENZ, D., SOARES, F.E.F., TOBIAS, F.L., HIURA, E., ARAÚJO, J.V. and BRAGA, F.R., 2018. Colonization and destruction of ants of the genus Camponotus sp. (Hymenoptera: Formicidae) in vitro by the fungus Pochonia chlamydosporia in the southeast region of Brazil. 3 Biotech, vol. 8, no. 8, pp. 333. http://dx.doi.org/10.1007/s13205-018-1365-1.

SILVA, J.M., NOVATO-SILVA, E., FARIA, H.P. and PINHEIRO, T.M.M., 2005. Agrotóxico e trabalho: uma combinação perigosa para a saúde do trabalhador rural. Ciência \& Saúde Coletiva, vol. 10, no. 4, pp. 891-903. http://dx.doi.org/10.1590/S141381232005000400013 .

SOARES, F.E.F., QUEIROZ, J.H., ARAÚJO, J.V., RODRIGUES, M.G.R., TAVELA, A.O., AGUIAR, A.R., LACERDA, T., FERRAZ, C.M., RANGEL, M.C.V., SENNA, T., ARAUJO, A.L., REGO, T.P., SENA, C.C. and BRAGA, F.R., 2015. Action of proteases of the nematophagous fungi Pochonia chlamydosporia on Ascaris suum eggs of collared peccary (Pecari tajacu). African Journal of Microbiological Research, vol. 9, no. 31, pp. 1883-1886. http:// dx.doi.org/10.5897/AJMR2015.7650. 